Прегледни чланак

343.9.02:341.45

doi:10.5937/zrpfns54-29642

Emina Radosavljević, Ph.D. Student

University of Novi Sad

Faculty of Law Novi Sad

ema_radosavljevic@yahoo.com

\title{
COMPLIANCE OF DOMESTIC CRIMINAL LEGISLATION IN THE FIELD OF INTERNATIONAL AND JUDICIAL COOPERATION WITH THE EU ACQUIS IN THE FIGHT AGAINST ORGANIZED CRIME - SECURITY ASPECT
}

\begin{abstract}
The area of the European Union (EU) is characterized by general liberalization, ie. „Free flow of people, goods, services, and capital”, which is why the organized crime with international elements seriously affects the security of entire regions. Given that no country, regardless of its resources, can confront the threats of the global environment on its own, the need to create a single legislative framework aimed at strengthening the internal security system of the EU and its member states have become necessary. The mentioned unified legislation leads to the centralization of the security area at the supranational level, ie. delegation of competencies of the Member States to the institutions of the Union.

In the global fight against organized crime, with the entry into force of the Law on Ratification of Stabilization and Association Agreements between the European Communities and their Member States, on the one hand, and The Republic of Serbia, on the other ${ }^{l}$ Serbia has committed itself to gradually harmonizing its national legal framework with acquis communautaire, as well as to apply them consistently. Given that, in this paper will be considered the harmonization of certain provisions of the Law on Organization and Competences of State Bodies in the Suppression of Organized Crime, Terrorism and Corruption, ${ }^{2}$
\end{abstract}

\footnotetext{
${ }^{1}$ Law on Ratification of the Stabilization and Association Agreement between the European Communities and their Member States, of the one part, and the Republic of Serbia, of the other part, „Official Gazette RS Gazette - International Agreements ”, No. 83/2008.

${ }^{2}$ Zakon o organizaciji i nadležnosti državnih organa u suzbijanju organizovanog kriminala, terorizma i korupcije (ZONDOSOKTK), „Sl.glasnik RS”, br. 94/16 i 87/18 - dr. zakon.
} 
ie. international cooperation in criminal matters systematized in Chapter 24 Justice, Freedom, and Security.

Keywords: organized crime, international cooperation, security.

\section{INTRODUCTION}

Unlike the period of the bipolar division of the world in which security was threatened by a „known enemy”, embodied in an ideologically opposed bloc of states, with clearly set and demarcated goals and predictable reactions, modern security threats come mainly from non-state, uncontrolled entities. ${ }^{3}$ Expansion of the mentioned threats, especially when it comes to organized crime, in addition turbulent social circumstances such as war, social unrest, etc. ${ }^{4}$, is a direct consequence of the opening of borders between states and general liberalization, which organized criminal groups used to expand their activities, but also to undertake new ones, in cooperation with new actors. Unlike their actions, the powers of the prosecuting authorities ended at the borders of the states on whose behalf they act, since there was no common security policy, nor were supranational judicial bodies established. ${ }^{5}$

Given the social danger that organized crime can pose, the international community initiated the signing of the Treaty on the Establishment of the EU in Maastricht, in 1992 as the most important integrative step after the founding act. ${ }^{6}$ Namely, the mentioned document defined, among other things, the common foreign and security policy, as well as cooperation in the field of justice and internal affairs.

It is also necessary to point out that the connection of terrorists with the actors of organized crime are inevitable, ${ }^{7}$ and that they are united by the need to finance their own activities, which is why both resort to committing crimes in order to acquire the necessary material resources. ${ }^{8}$ There are criminal acts with

${ }^{3}$ Dr Ljubomir Stajić, „Postmoderni terorizam, organizovani kriminal i korupcija kao savremeni bezbednosni izazovi, rizici i pretnje”, Zbornik radova Pravnog fakulteta u Novom Sadu (Zbornik radova PFNS)(ur. prof. dr Rodoljub Etinski) 2/2006,380.

${ }^{4}$ Milan Škulić, „Organizovani kriminalitet, pojam i krivičnoprocesni aspekti”, Beograd 2003, 77.

${ }^{5}$ Vojislav Đurđić, „Evropski nalog za hapšenje”, Zbornik radova Pravnog fakulteta u Novom Sadu (Zbornik radova PFNS) (ur. prof dr Slobodan Orlović) 1/2012, 22.

${ }^{6}$ Vanda Božić, Saša Knežević, Željko Nikač, „Evropski nalog za hapšenje kao mehanizam ekstradicije u međunarodnoj krivičnopravnoj saradnji”, Zbornik radova Pravnog fakulteta u Nišu (Zbornik radova PFN) (ur prof. dr Irena Pejić), 79/2018, 16.

${ }^{7}$ Nataša Dragojlović Ćirić: „Strateški odgovor SAD I EU na terorizam”, Nacionalna i globalna bezbednost, Centar za civilno-vojne odnose, Beograd, 2005, 84.

${ }^{8}$ Christopher Daase, ,,Terrorism and Organized Crime: One or Two Challenges?” Transnational Terrorism, Organized Crime and Peace-Building, Palgrave Macmillan, London, 2010, 57. 
recognizable handwriting of members of organized criminal groups: drug production and trafficking, robberies, money laundering, kidnappings, human trafficking, etc.

However, unlike terrorists who act for ideology and political reasons, ${ }^{9}$ organized crime excludes the existence of any political or nationalist ideological activity, ${ }^{10}$ which makes the fight against it even more complicated.

\section{PLACE AND SIGNIFICANCE OF THE FIGHT AGAINST ORGANIZED CRIME IN CERTAIN EU DOCUMENTS}

The fight against organized crime has a significant place in several recent documents of the Union, such as the EU Global Strategy for Foreign and Security Policy ${ }^{11}$ - a strategic document that contains the essential principles and basic directions of its foreign policy. The distribution of world power is a dynamic process that also affects the geopolitical position of the EU and requires constant analysis of its interests, principles, and priorities for action. Some of its members face various security threats - in some, for example, economic security is more endangered, in others, there is a greater danger of illegal migration. However, all of them, to a greater or lesser extent, share the challenges of the fight against organized crime, which means that they can only oppose it by working together. For this reason, the prevention and combating of organized crime is envisaged as an obligation not only in the negotiating Chapter 24 but also in Chapter $31-\mathrm{Com}$ mon, foreign, defense, and security policy, which is why the EU is seeking reforms in the field of justice, security and defense.

The EU Strategy for the Western Balkans, ${ }^{12}$ which, like the EU Global Strategy on Foreign and Security Policy, defines guidelines for meeting the conditions for accession to the Union, emphasizes the rule of law, given the significant interdependence of public and private interests and links to organized crime and corruption at all levels of government. Therefore, the need of states for specialization and strengthening of the judiciary, as well as the establishment of special police units at prosecutors' offices, is significantly pointed out. Moreover, the chapter „Credible Enlargement Perspective - Requires European Union Support”

\section{${ }^{9} \mathrm{Ibid}, 55$.}

${ }^{10}$ M. Škulić, (2003).

${ }^{11}$ Globalna strategija EU o spoljnoj i bezbednosnoj politici - zajednička vizija, zajedničko delovanje - jača Evropa, Savet EU, 28.06.2016.

12 The full title of the Strategy published in March 2018 by the European Commission is „Communication from the European Commission to the European Parliament, the Council, the European Economic and Social Committee and the Committee of the Regions - A credible enlargement perspective for the Western Balkans and increased EU engagement in the Western Balkans." 
emphasizes the need for stronger Union involvement in the Western Balkans in areas of common interest, such as justice, home affairs, security, and the fight against organized crime. In addition, it is emphasized that the most important for the successful resolution of security threats is the improvement of strategic and operational cooperation between the EU and the Western Balkans in the field of security, through relevant agencies as well as in law enforcement and information exchange at all levels.

\section{NATIONAL SECURITY AND THE FIGHT AGAINST ORGANIZED CRIME}

Some authors point out that organized crime records constant growth and increased aggression, and that it is set up as a system parallel to the state system, which is why it can be described as an association that operates outside the control of public authorities. ${ }^{13}$ Organized crime has the ability to quickly adapt to the general social and economic conditions and to almost unmistakably detect areas in which extremely high material benefits are illegally realized. ${ }^{14}$

In addition, it is characterized by the permanent connection of a large number of persons in criminal ,associations" in which there is a relationship of subordination, division of roles and loot, and conspiratorial action. Organized crime is given special weight by the planned, permanent, secret, professionalized and targeted commission of criminal acts that excludes all coincidence and negligence, while in achieving its goal it uses intimidation and violence and all forms of corruption. ${ }^{15}$ Finally, organized crime seeks to infiltrate the country's political system, which means establishing links between its actors and government officials. ${ }^{16}$ This ,trait” is especially dangerous for national security, bearing in mind that the mentioned relations can cause distrust of citizens in the rule of law.

Traditionally, the basic motive of criminals was to gain significant material benefits. However, today, due to the ,weight" of the loot, they need to put part of the illegally acquired money into legal flows, ie to „wash” or „peel” it, which directly destroys the economic security of the state. ${ }^{17}$ In addition, one of the goals

${ }^{13}$ Momčilo Grubač, „Organizovani kriminal u Srbiji kao pojava novijeg vremena”, Borba protiv organizovanog kriminala u Srbiji - od postojećeg zakonodavstva do sveobuhvatnog predloga reforme, Institut za uporedno pravo, Beograd 2008, 31.

${ }^{14}$ The increased development of science and technology and their feedback on society has certainly contributed to this, which further leads to the complication of negative social phenomena.

${ }^{15}$ Tatjana Lukić, „Posebnosti krivičnog postupka za organizovani kriminal, terorizam i korupciju", Novi Sad, 2008, 32.

${ }^{16}$ Lj. Stajić, Zbornik radova PFNS, 2/2006, 389.

${ }^{17}$ Dr Ljubomir Stajić, Osnovi sistema bezbednosti sa osnovama istraživanja bezbednosnih pojava, Novi Sad 2015, 192. 
is to acquire a certain type of power, most often political, which would enable them to influence the adoption of certain state decisions by non-institutional and illegal actions. Consequently, the fight against organized crime is a central part of the security strategies of modern states as a basic strategic document that regulates the most important issues of national security interest and which represents respect for generally accepted standards of security organization of modern states. ${ }^{18}$ As for The Republic of Serbia, the National Security Strategy states, ${ }^{19}$ among other things, that organized crime in Serbia, and especially in the southern province, is represented through illicit drug trafficking, illegal migration, human trafficking, the possibility of proliferation of weapons of mass destruction and proliferation of conventional weapons.

Although it has long been defined as an internal form of threat, organized crime has long had an international dimension, threatening the security and stability of the state from the outside. ${ }^{20}$ This is indicated by some features of organized crime in the 21st century, such as organizing criminal activities at the global level, increased degree of transnational ties and forms of cooperation between criminal organizations, multiple increases in power to influence state security, undermining democratic institutions, slowing economic growth. etc.

In the year of the adoption of the National Security Strategy, the Government of the Republic of Serbia also adopted the National Strategy for the Fight against Organized Crime. ${ }^{21}$ In the mentioned document, it is stated that Serbia, in cooperation with the international community, will develop its own capacities for the prevention of all forms of organized crime, especially against corruption and its presence in state structures.

As the basic goals of the Strategy, the following are also stated:

1. strengthening the proactive approach in preventing organized crime;

2. improving the efficiency of prevention of organized crime by adequate preventive and repressive activities and confiscation of property derived from criminal offenses;

3. harmonization of national legislation with international norms in the field of fight against organized crime;

4. increasing the capacity (human and material-technical) of all state bodies, participants in the prevention of organized crime;

${ }^{18}$ Dr Ljubomir Stajić, Nenad Radivojević, Vladan Mirković, „Neki aspekti politike unutrašnje bezbednosti kao elementa Strategije nacionalne bezbednosti Republike Srbije”, Zbornik radova Pravnog fakulteta u Novom Sadu ( ur. prof.dr Slobodan Orlović) 4/2017, 1327.

${ }_{19}$ Odluka o usvajanju Strategije nacionalne bezbednosti Republike Srbije, ,Službeni glasnik RS”, 2009/88.

${ }^{20}$ Lj. Stajić (2015).

${ }^{21}$ Nacionalna strategija za borbu protiv organizovanog kriminala „Sl.glasnik RS”, br.23/09. 
5. increasing cooperation at the national, regional, and international level;

6. strengthening coordination between state bodies, the private sector, and civil society.

\section{JUDICIAL COOPERATION IN CRIMINAL MATTERS}

Since state borders are not an obstacle to organized crime, its suppression is part of the EU's foreign policy. ${ }^{22}$ In that sense, the need to harmonize the social peculiarities of each country with foreign solutions is also important. ${ }^{23}$

The terrorist attacks of September 11, 2001, in the United States significantly accelerated the adoption of a single legislative framework aimed at the effective application of the principles of mutual recognition of court decisions, avoidance of lengthy ratification procedures and potential reservations of states to certain provisions. ${ }^{24}$

The issue of international cooperation in criminal matters in Serbia is regulated by systemic laws, and the basic issues of cooperation are defined by the Law on International Legal Assistance in Criminal Matters, ${ }^{25}$ the Law on Organization and Competences of State Bodies in Combating Organized Crime, Terrorism and Corruption, ${ }^{26}$ and the Law on Confiscation from criminal cases, ${ }^{27}$ etc. In addition, in order to improve judicial cooperation in criminal matters, Serbia has signed 24 multilateral agreements of the Council of Europe $(\mathrm{CoE})$ which regulate this matter, as well as a number of conventions of the UN and its organizations. Also, it is a signatory of 52 bilateral agreements with 31 countries, in which all or some forms of cooperation are defined. In light of the improvement of cooperation with EU members, Serbia is a signatory to 31 bilateral agreements with 19 countries that regulate different patterns and levels of cooperation in criminal matters.

Regarding Framework Decision 2002/584 / JHA and the European Arrest Warrant and the surrender procedure between member states, Serbia withdrew its reservation to Article 6 of the European Convention, which prohibits the extradition of its own nationals, bearing in mind that the Constitution of the Republic of Serbia $^{28}$ does not prohibit extradition. On the other hand, the Council's framework decisions on mutual recognition of convictions in criminal cases imposing prison sentences or measures involving imprisonment with a view to their execution in

${ }^{22}$ Letizia Paoli and Cyrille Fijnaut, „,The Initiatives of the European Union and the Council of Europe", Organised Crime in Europe, Concepts, Patterns and Control Policies in the European Union and Beyond (eds. Cyrille Fijnaut Letizia Paoli), London, 2004, 626.

${ }^{23} \mathrm{M}$. Grubač, 34.

${ }^{24}$ V. Božić, S.Knežević, Ž. Nikač, Zbornik radova PFN, 79/2018, 19.

${ }^{25}$ Zakon o međunarodnoj pravnoj pomoći u krivičnim stvarima, „Sl. glasnik RS”, br.20/09.

${ }^{26}$ ZONDOSOKTK

${ }^{27}$ Zakon o oduzimanju imovine proistekle iz krivičnog dela, ,Sl. glasnik RS”, br.32/13 i 94/16.

${ }^{28}$ Ustav Republike Srbije, „Sl. glasnik RS”, br.98/06. 
the EU has not yet become part of the legal system of the Republic of Serbia. Namely, as some authors explain, ${ }^{29}$ the principle of mutual recognition of court decisions imply that the judicial authority of one member state automatically recognizes and enforces the decisions of the courts of another member state. In this sense, the harmonization of national laws with EU norms should significantly accelerate cooperation in criminal matters, bearing in mind that the traditional way of cooperation in cross-border or transnational crime is too slow for the purposes of criminal justice. ${ }^{30}$

The consequences of mutual recognition imply that the executing State has „lost" part of its sovereignty over full control over the execution of judgments in its territory. ${ }^{31}$ Also, mutual cooperation includes detention and extradition of persons related to the commission of a criminal offense, examination of witnesses by video link, the realization of controlled deliveries, the formation of joint investigation teams, setting requests for interception of electronic communications, etc. In this sense, the first legal instrument based on the principle of mutual recognition of judicial decisions in criminal matters among the EU Member States is the European Arrest Warrant. ${ }^{32}$ The Law on Organization and Competences of State Bodies in the Suppression of Organized Crime, Terrorism and Corruption created an essential framework for efficient and effective fight against the most serious forms of crime, and defined and harmonized certain solutions on joint work of state bodies and organizations. On this occasion, we will analyze the provisions related to the functioning of liaison officers, the formation of task forces, and the engagement of financial forensics.

\subsection{Liaison officers}

In addition to the fact that ZONDOSOKTK envisages the specialization of state bodies responsible for criminal prosecution of defendants for organized crime, it also defines the cooperation of institutions that may have information of importance for prosecuting authorities with the Prosecutor's Office for Organized Crime and special departments of higher public prosecutor's offices. Namely, the essence of the mentioned cooperation is reflected in the appointment of at least one liaison officer in institutions such as the Tax Administration, Customs Administration, Tax Police ${ }^{33}$ in order to connect and efficiently submit data to the

${ }^{29}$ V. Đurđić, Zbornik radova PFNS, 1/2012, 24.

${ }^{30}$ Sandra Stojković, „Uzajamno priznavanje odluka u krivičnim stvarima i prava okrivljenog lica”, Novi Sad 2016, 58.

${ }^{31}$ Steve Peers, „EU Justice and Home Affairs Law”, New York 2011, 663.

${ }^{32} \mathrm{Ibid}, 25$.

${ }^{33}$ Liaison officers are also appointed in the National Bank of Serbia, the Anti-Money Laundering Administration, the Anti-Corruption Agency, the Republic Geodetic Authority, the Business Registers Agency and others. Also, if the competent public prosecutor so requests, liaison officers shall be appointed in other bodies and organizations. 
Prosecutor's Office for Organized Crime and special departments of higher public prosecutor's offices for the suppression of corruption. ${ }^{34}$ Also, if the need arises, liaison officers with the status of a civil servant can be temporarily transferred to the Prosecutor's Office for Organized Crime and special departments of higher public prosecutor's offices for the suppression of corruption.

\subsection{Joint task forces}

Given that the fight against organized crime requires a multidisciplinary approach and rapid response by law enforcement agencies, ZONDOSOKTK foresaw the formation of strike groups. These so-called Investigative teams represent modern types of activities of law enforcement bodies, ${ }^{35}$ which include representatives of state bodies and organizations whose goal is otherwise the suppression of criminal acts in the field of organized crime. ${ }^{36}$ In that sense, they consist of police officers and representatives of other state bodies who have knowledge and the practical experience that can contribute to the detection of criminal acts, and who, thanks to this form of cooperation, can exchange information gathered on the ground faster and more openly, without submitting formal requests. ${ }^{37}$ Joint task forces whose formation is facultative can be formed in the Prosecutor's Office for Organized Crime and special departments of higher public prosecutor's offices for the suppression of corruption with the aim of detecting criminal acts and prosecuting persons who are the subject of their work. They are managed by the prosecutor or his deputy who is in charge of conducting the pre-investigation procedure in a specific case, and they function until the end of the case.

\subsection{Financial forensics}

Given that modern criminal legislation is aimed at identifying the main actors, seizing illegally acquired property and preventing its entry into legal channels, the engagement of financial forensics can play a key role in these activities. ${ }^{38}$ Financial forensics are civil servants who possess certain professional, non-legal

\footnotetext{
${ }^{34}$ Tanja Kesić, Predrag Ćetković i Milan Žarković, „Analiza primene novih zakonskih rešenja u suzbijanju korupcije u Republici Srbiji”, Bezbednost (ur. Božidar Otašević i dr.) 1/20, 12.

35 Ibid.

${ }^{36}$ In addition, joint task forces are formed with the aim of detecting, prosecuting and prosecuting the crimes of murder of representatives of the highest state bodies, the crime of armed rebellion, the crime against official duty, the crime of giving and receiving bribes in connection with voting, crimes against economy, etc.

${ }^{37}$ Ibid.

${ }^{38}$ Goran Bošković, „Metodi finansijske istrage u suzbijanju organizovanog kriminala”, Društveni aspekti organizovanog kriminala (urednici Aleksandar Fatić i Božidar Banović) Institit za međunarodnu politiku i privredu, Beograd, 2011, str.63.
} 
knowledge in the field of banking and finance through which information is obtained on financial flows of illegally acquired money, economic entities that are used for that purpose, possible data on other crimes with the ultimate goal of prosecution the perpetrator. It is also possible to locate illegally acquired funds and create grounds for initiating proceedings for their seizure. ${ }^{39}$ Thus, financial investigations can be defined as economic-criminal investigations with the inclusion of previous circumstances and the environment, which are a complement to measures to combat organized crime. ${ }^{40}$ According to the Law on Organization and Competences of State Bodies in the Suppression of Organized Crime, Terrorism and Corruption. ${ }^{41}$ The Financial Forensics Service may be established in the Prosecutor's Office for Organized Crime and special departments of higher public prosecutor's offices for the fight against corruption.

\section{CONCLUSION}

Modern security threats, including organized crime, can hardly be divided internal, ie national, and external, which is why the creation of a single legislative framework is a natural consequence of their suppression. Namely, such a framework means their recognition and definition as global security risks that require a global response. Among other things, this implies the establishment of new police and security bodies as well as the delegation of certain competencies of member states to EU institutions.

The suppression of organized crime in order to protect the vital values of society is regulated in Serbia by strategic and legislative regulations that are continuously harmonized with the EU legal framework. Namely, by territorial notification, the actors of serious forms of crime got huge opportunities for maneuvering and committing criminal acts, for connecting with organized criminal groups of other countries and concealing money transactions. Accordingly, the foundation of national and supranational activities is a proactive fight against organized crime with an emphasis on inter-ministerial cooperation of all competent state bodies, both domestically and internationally. Also of great importance is the fact that Serbia, in addition to complying with high legal standards, has shown a significant level of success in the fight against organized crime in practice by signing bilateral and multilateral agreements that allowed it to exchange operational information in a timely manner. These results also contributed to the specialization of state bodies, especially in terms of finance and banking. Achieving satisfactory results in the fight against organized crime requires efficient and effective

\footnotetext{
${ }^{39}$ Ibid 79.

${ }^{40}$ T. Lukić, 102.

${ }^{41}$ ZONDOSOKTK, art. 19
} 
international cooperation, which includes timely exchange of information, concentration of material and intellectual resources with a view to a unified approach to work, proper assessment of information and determining the focus of the investigation.

\section{REFERENCES}

Vanda Božić, Saša Knežević, Željko Nikač, „Evropski nalog za hapšenje kao mehanizam ekstradicije u međunarodnoj krivičnopravnoj saradnji”, Zbornik radova Pravnog fakulteta u Nišu, 79/2018.

Momčilo Grubač, „Organizovani kriminal u Srbiji kao pojava novijeg vremena”, Borba protiv organizovanog kriminala u Srbiji - od postojećeg zakonodavstva do sveobuhvatnog predloga reforme, Beograd, 2008.

Nataša Dragojlović Ćirić, „Strateški odgovor SAD I EU na terorizam”,Nacionalna i globalna bezbednost, Beograd, 2005.

Tatjana Lukić, „Posebnosti krivičnog postupka za organizovani kriminal, terorizam i korupciju", Pravni fakultet, Centar za izdavačku delatnost, Novi Sad, 2008.

Ljubomir Stajić, „Osnovi sistema bezbednosti sa osnovama istraživanja bezbednosnih pojava", Pravni fakultet Univerziteta u Novom Sadu, 2015.

Sandra Stojković, „Uzajamno priznavanje odluka u krivičnim stvarima i prava okrivljenog lica", Pravni fakultet Univerziteta u Novom Sadu, 2016.

Ljubomir Stajić, „Postmoderni terorizam, organizovani kriminal i korupcija kao savremeni bezbednosni izazovi, rizici i pretnje", Zbornik radova Pravnog fakulteta Univerzieta u Novom Sadu, 2/2006.

Milan Škulić, Organizovani kriminalitet, pojam i krivičnoprocesni aspekti, Dosije, Beograd, 2003.

Ljubomir Stajić, Nenad Radivojević, Vladan Mirković, „Neki aspekti politike unutrašnje bezbednosti kao elementa Strategije nacionalne bezbednosti Republike Srbije", Zbornik radova Pravnog fakulteta u Novom Sadu, 4/2017.

Vojislav Đurđić, „Evropski nalog za hapšenje”, Zbornik radova Pravnog fakulteta u Novom Sadu, 1/2012.

Tanja Kesić, Predrag Ćetković, Milan Žarković, „Analiza primene novih zakonskih rešenja u suzbijanju korupcije u Republici Srbiji”, Bezbednost, Beograd, 2020.

Goran Bošković, „Metodi finansijske istrage u suzbijanju organizovanog kriminala”, Društveni aspekti organizovanog kriminala, Institit za međunarodnu politiku i privredu, Beograd, 2011.

Christopher Daase, „Terrorism and Organized Crime: One or Two Challenges?” Transnational Terrorism, Organized Crime and Peace-Building, Palgrave Macmillan, London, 2010, 55.

Steve Peers, „EU Justice and Home Affairs Law”, third edition, Oxford EU Law Library, New York, 2011.

Letizia Paoli and Cyrille Fijnaut, „The Initiatives of the European Union and the Council of Europe", Organised Crime in Europe, Concepts, Patterns and Control Policies in the European Union and Beyond ( ed. Cyrille Fijnaut Letizia Paoli), London, 2004. 
Legal regulations:

Ustav Republike Srbije, „Sl. glasnik RS”, br.98/2006

Zakon o međunarodnoj pravnoj pomoći u krivičnim stvarima, „Sl. glasnik RS”, br. 20/2009)

Zakon o organizaciji i nadležnosti državnih organa u suzbijanju organizovanog kriminala, korupcije i drugih posebno teških krivičnih dela, ,Sl.glasnik RS”, br 94/2019

Zakon o oduzimanju imovine proistekle iz krivičnog dela, ,Sl. glasnik RS”, br.32/2013 i $94 / 2016$

Zakon o potvrđivanju sporazuma o stabilizaciji i pridruživanju između Evropskih zajednica i njihovih država članica, sa jedne strane, i Republike Srbije, sa druge strane, ,Sl. glasnik RS - Međunarodni ugovori”, br.83/2008)

Nacionalna strategjja za borbu protiv organizovanog kriminala, „Сл.гласник РС”, бp. $23 / 09$.

Odluka o usvajanju Strategije nacionalne bezbednosti Republike Srbije, ,Službeni glasnik RS", 2009/88 


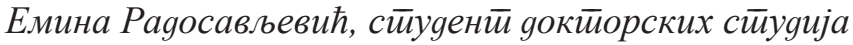

Универзииетеи у Новом Саgу

Правни факулиетеи у Новом Саgу

ema_radosavljevic@yahoo.com

\section{Усклађеност домаћег кривичног законодавства у области међу- народне и правосудне сарадње са правним тековинама ЕУ у борби против организованог криминалитета - безбедносни аспект}

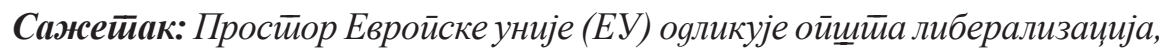

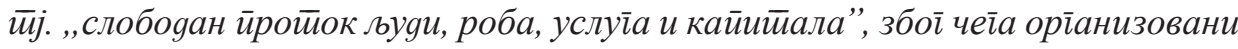

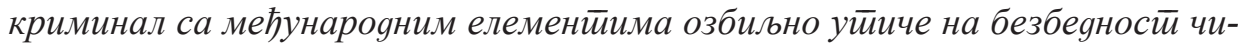
йавих реіиона.

С обзиром gа ни јеgна држава, без обзира на своје ресурсе, не може сама gа се суйройсииави иреитьама иллобалнои окружења, као неойходна се јавила

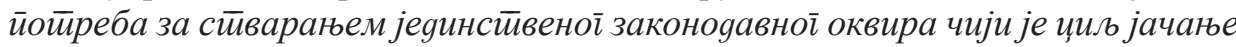
систиема унуйращње безбеgностии саме ЕУ као и њених држава чланица.

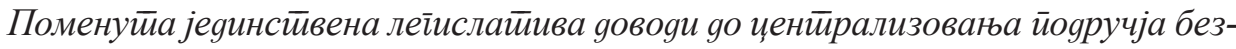
беgностии на суйранационалном нивоу, йј. gелеїирања наялежностии gржава чланица на инстиитичиије Уније.

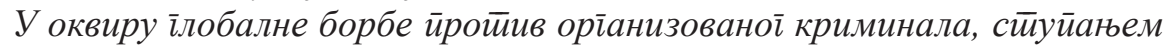

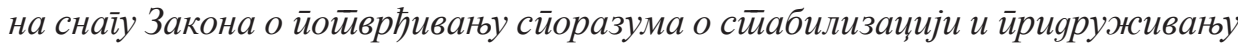
између Евройских зајеgница и њихових држава чланница, са јеgне сйране, и Рейублике Србије, са gруіе стиране, ${ }^{42}$ Србија се обавезала gа ће йосиеиеиено усклађиватии национални ирравни оквир са ирравним иековинама ЕУ, као и gа

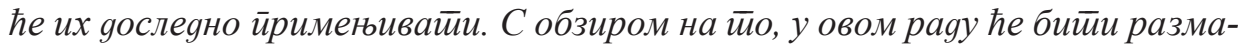

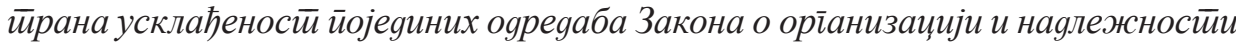
яржавних орі̄ана у сузбијағу оріанизованог криминала, йероризма и коруйиије, ${ }^{43} \bar{u} j$. међунаровне сараяње у кривичним стиварима које су систиематиизоване у Пойлављу 24 - Правgа, слобоgа и безбеgности.

Кључне речи: орїанизовани криминал, међународна сараяња, безбеgности.

Датум пријема рада: 30.11.2020.

42 Закон о потврђивању споразума о стабилизацији и придруживању између Европских заједница и њихових држава чланица, са једне стране, и Републике Србије, са друге стране, „Сл. гласник РС - Међународни уговори”, бр.83/2008.

43 Закон о организацији и надлежности државних органа у сузбијању организованог криминала, тероризма и корупције (ЗОНДОСОКТК), „Сл. Гласник РС”, бр. 94/16 і 87/18 - др. закон. 